\title{
Using Principles of the Instructional Systems Design Approach for Implementing Open-Source Learning Management System in Higher Education
}

\author{
Moti Frank $^{*}, 1$ and Abigail Barzilai ${ }^{2}$ \\ ${ }^{I}$ Center for the Advancement of Teaching, HIT - Holon Institute of Technology, Holon 58102, Israel \\ ${ }^{2}$ Center for the Advancement of Teaching, Technion - Israel Institute of Technology, Haifa 32000, Israel
}

\begin{abstract}
This paper discusses the issues associated with teaching and learning when developing course web sites based on principles of the instructional systems design (ISD) approach. The organizational and operational aspects are presented first, following by a discussion of pedagogical aspects. Three pedagogical issues related to course web sites are discussed in detail - active learning, computerized feedback, and the effects on learning of using multimedia. Some findings, based on collected data and the authors' experiences, are also presented and discussed. The conclusions are that the advanced technology exists but it seems that instructors in higher education still tend to build course web sites that underutilize the technology's potential. On the other hand, using technology simply because it is there does not assure effective learning. Technology must be a means - not the aim. The pedagogical considerations and the ways of using the technology to achieve the pedagogical benefits are what is important.
\end{abstract}

\section{INTRODUCTION}

Over the past few years, with the rapid development of technology, we see crystallization of three approaches for using e-learning in higher education. The first approach is a lecture-based course also available through a web site (course web site). In other words, lectures are given in the traditional manner but in parallel a web site is built on behalf of the course for exercises and practice drills, supplement, enrichment, and in-depth study of the subject. The second approach - a fully on-line asynchronous course - requires only a very limited number of classroom sessions. The primary teaching is conducted through the course web site. This contrasts with the third approach - synchronous distance learning. In this approach, teaching resembles, in some of its features traditional teaching yet nevertheless, the teacher and his or her students are physically distant from one another.

This paper focuses on the first and second approaches and discusses the advantages and challenges that these approaches offer lecturers. The aim of the paper is to consider issues associated with teaching and learning when developing course web sites based on principles of the instructional systems design (ISD) approach (Banathy, 1987). The innovation here is the application of the ISD approach to elearning course. Instructional Systems Design, also known as Instructional Design, is the analysis of learning needs and systematic development of instruction. It is often called ADDIE (Analysis, Design, Development, Implement, Evaluate). Instructional designers often use instructional technology as a method for developing instruction. A major goal of good instructional design is to integrate content with presentation. With the new current technologies, instructional designers have new options for designing and developing

*Address correspondence to this author at the Center for the Advancement of Teaching, HIT - Holon Institute of Technology, Holon 58102, Israel; E-mail: frankm@hit.ac.il content. Various options of teaching and learning strategies that can be used in web-based learning environments and based on ISD will be discussed in this paper. Some findings, based on collected data and the authors' experience will be presented and discussed.

\section{DEVELOPING A COURSE WEB SITE FOR LEC- TURE-BASED COURSE}

\section{Some Pedagogical Benefits that May Be Derived from Course Web Site}

In recent years we have been witnessing, in higher education, considerable growth in the number of courses with web sites meant to serve as tools for augmenting traditional teaching. A well designed course web site will function as a complementary tool to the classroom lessons and raise the learning effectiveness through active and interactive learning. Using Learning Management System enables faculty with little or no pedagogical knowledge to extract some ISD principles that are inherent in the system.

Using the internet as a delivery medium can lead to a tendency to design instruction based only on the technological capabilities, rather than on pedagogy considerations, core instructional elements, the needs of the learner, and the achievement of independent learning strategies. Technology can provide not only presentational and organizational functions, but can also support communication, feedback and interaction between students and teachers. The instruction strategy of such courses needs to be based on theories about learning and how knowledge is constructed (Oliver \& McLoughlin, 1999).

Many researchers refer to organizational and operational advantages that may be achieved from a course web site such as accessibility and flexibility (e.g. Ash, 2000; Montgomerie \& Harapnuik, 1997; Brinkerhof, \& Koroghlanian, 2005). However, we focus here on the pedagogical benefits. One inherent advantage of a course web site is the ability to implement 
four dimensions of "good teaching" (Hativa, 2000) - applying active and interactive learning principles (for example, the teacher can place challenging inquiry tasks, present and discuss paradoxes and contradictions, and initiate reflection on the learning processes), using multimedia and be exposed to multiple realities, organizing the course and its lessons, and providing (automatic) immediate feedback to students as well as hints and directions on how to continue in case of mistakes.

A course web site may nurture development of independent learning. The learning through the course web site is according to the pace, style and level that is suitable for each learner. By using the course web site, if well designed, learning can reach a depth unlikely to be attained in the face-toface lessons, since students can invest as much time and effort as required, each according to his or her learning tempo. This contrasts with synchronous and frontal teaching classes, which have a time limit and progress at a uniform pace that is not necessarily suitable for each student. When the teacher assigns questions/tasks through the course web site students have enough time to think before giving their answers - a luxury not always available in frontal or synchronous classes (Bhattacharya, 1999; Branon and Essex, 2001). And finally, the asynchronous forum can promote active learning and critical thinking (Garrison et al., 2000).

\section{Challenges when Using a Course Web Site}

Lister (1999) noted that in certain cases the problem of motivation in asynchronous lessons may arise. Lacking a serious incentive, students may not make the effort needed to learn through the web site.

In asynchronous lessons the teacher cannot see the students' reactions to the study material. He or she may miss out on facial expressions or body language, for instance (Wolcott, 1995; Hill, 1997). In fact, several researchers related to the difficulties arising from lack of eye-contact between teacher and student, as in distance learning. Willis and Dickinson (1997), for example, wondered whether teachers can be effectual if they are unable to maintain eye-contact with their students, or to observe students' non-verbal behavior. In order to create a course web site teachers must invest great effort in writing up the course content (in the case that these were not prepared beforehand).

\section{USING THE COURSE WEB SITE FOR DELIVERING FULLY ON-LINE ASYNCHRONOUS COURSE}

\section{Benefits of Fully On-Line Asynchronous Course}

A fully on-line course is inherently an asynchronous course. Such courses require a very limited number of meetings in a classroom setting. Most teaching is executed through the course web site. Many researchers refer to organizational and operational advantages that may be achieved from asynchronous teaching such as accessibility and flexibility in time and space, the option for delivering assignments through the web, the possibility to transfer the course to a relatively large number of students (an economic advantage), and the possibility to store statistical data for applying it to follow-up on students' progress. However, in this paper we would like to focus on the pedagogical benefits.
In courses where there are a large number of students, asynchronous courses have an advantage over traditional teaching. In the former, each student can ask the lecturer a question when he or she needs or wants to and receive an answer (through e-mail, for instance), whereas in the latter, the teacher cannot hope to respond to each of the students. Moreover, feedback is given only to those who dare ask a question in front of so many co-students (Willis and Dickinson, 1977). Shy students are liable to hesitate in a frontal teaching or synchronous course, in which all the students will hear the question. In frontal teaching, either the time allotted for questions is very limited or students must approach the teacher during the latter's office hours (which are not always at times convenient for the student).

Other investigators have discussed other advantages that may be achieved when using asynchronous communication (comparing to synchronous communication). Branon and Essex (2001, p. 36), for example, noted that "distance educators have found asynchronous communication useful for: encouraging in-depth, more thoughtful discussion; communicating with temporally diverse students; holding ongoing discussions where archiving is required; and giving all students the opportunity to respond to a topic."

In an asynchronous course study and learning can reach a depth unlikely to be attained in a synchronous course, since students can invest as much time and effort as required, each according to his or her learning tempo. This contrasts with synchronous and frontal teaching classes, which have a time limit and progress at a uniform pace that is not necessarily suitable for each student.

The advantages teachers have in asynchronous teaching: the ability to continually update learning material, the capacity to send messages quickly to all students in the course, links to data bases and relevant internet sites, the possibility to automatically check exercises and manage grades. Another benefit, which appears surprising perhaps, that in fully on-line courses with a large number of students teachers get to know the students, or at least some of them, better than that in normal frontal courses. The acquaintance is usually developed through email correspondence or the course forum. Frank, Reich, \& Humphries (2002) found that in asynchronous distance learning the teacher is able to develop a greater personal connection with students through the use of e-mail than he/she is able to develop in a conventional classroom. Brown (2000), claim that In conventional classroom a dominant student may monopolizes the discussion (Brown, 2000), but in distance learning such a situation [is] unlikely to happen. However, there are numerous studies that indicate a problem of uneven participation for example in asynchronous discussion forums (Strijbos, et al., 2007). Finally, an improved level of social presence can increase the level of interactions in online forums (Tu \& McIsaac, 2002).

\section{Challenges when Using a Fully On-Line Asynchronous Mode}

Lister (1999) noted that the responsibility for learning is on students, who are meant to log in every so often and study and this may be a problem for those with low motivation. Freedman (1998, p. 69) stressed the proximity of teachers and students in regular classes. In his opinion, some students prefer standard face-to-face classes that provide warmth, a 
feeling of intimacy and help when problems crop up. Computer-aided teaching, synchronous and asynchronous, are not, according to Freedman, suited to every student: "The main aspect in the interaction between teacher and students relates to the affinity between them. The students want teachers who are able to give them human warmth and even an intimate attitude, and can help them to solve their personal problems".

According to Wolcott (1995) and Hill (1997), the interaction in distance learning is less than that of face-to-face learning. The teacher cannot see the students' reactions to the study material. He or she may miss out on facial expressions or body language, for instance. In fact, several researchers related to the difficulties arising from lack of eyecontact between teacher and student, as in distance learning. Willis and Dickinson (1997), for example, wondered whether teachers can be effectual if they are unable to maintain eye-contact with their students, or to observe students' non-verbal behavior.

Finally, teachers have two more problems with fully online courses. First, teachers must invest great effort in writing up course content (in the case that these were not prepared beforehand). And second, teachers cannot respond spontaneously to ongoing events, as teachers in standard classes can.

\section{METHOD}

\section{The Technion E-Learning Policy}

The Technion - Israel Institute of Technology is Israel's leading technology university. It has 19 engineering and science faculties, in which approximately 13,500 students are enrolled. About 10,000 of these are undergraduates. The remainders are graduates. Over 800 courses are open to students each semester.

The Technion's e-learning policy is that undergraduate and graduate studies must continue to be taught in the traditional fashion of lectures and tutorials. Nevertheless, the Technion encourages its teaching staff to build course web sites for their courses for enrichment, in-depth study, review and practice. When the Technion started its e-learning project, the WebCT system was selected as its Learning Management System (LMS). However, the Technion administration allowed interested faculties to develop Content Management Systems (CMS) on their own for internal faculty purposes. The Technion management, following a recommendation by the e-learning committee decided recently to switch from WebCT to Moodle. The rationale behind the decision to shift from WebCT to Moodle was similar to the rationale behind the same decision taken by Dublin City University (McMullin \& Munro, 2004). During the decisionmaking process we used also the criteria listed in Commonwealth of Learning LMS Open Source Report (2003).

\section{What is Moodle?}

Moodle is a Learning Management System, an opensource software package designed using sound pedagogical principles to help educators very easily to create effective on-line courses. Moodle has many features expected from an e-learning platform, including synchronous and asynchronous communication tools, content management, application sharing, assessment and self-evaluation tools, interactive learning tools, and management and administration tools. The system allows the lecturer (usually assisted by a graduate student) to choose between various techniques for organizing his or her web-based course and to implement pedagogic principles to accompany each course. It enables the instructor to choose between fully online courses and blended learning. See examples in Figs. (1-3) below.

\section{The Evaluation Program}

The Center for the Advancement of Teaching is conducting a continuous evaluation of the program, which is essential to it success. At the start of the project, it was clear that the process would be gradual. Therefore, two stages for building the course web sites were delineated. In the first stage, a standard web site would include administrative information and course content. In the second stage, course instructors were asked to add interactive components, such as tutorial exercises (in the form of multiple-choice questions, for example) to enable students to receive immediate feedback about their progress and elements such as simulations and animations, management games, model building and running, and execution of team projects.

From our continuous monitoring of the program's progress, two main contrasting conclusions can be drawn. The first is related to the impressive pace at which implementation of the Internet-enabled academic instruction has grown at the Technion. Many lecturers adopted the technology within a short time. The second, contrasting conclusion relates to the still limited pedagogical range of the implemented activities. Most instructors use course web sites only in the most basic way: as content providers rather than as tool that facilitate students' participation, communication, and collaboration.

By the year 2000, a limited number of course web sites had been built, under the initiative of lone lecturers who knew how to build internet sites. At that point (the beginning of 2000), the Technion initiated its e-learning project, in its present form, and up to the moment of writing this paper (mid 2007), about 1,300 course web sites have been built. Around 1100 of the web sites are based on the Moodle platform; the other sites were built by teaching staff as independent web sites or using the content management systems developed in-house by the respective faculties.

\section{The Data Collecting Tools}

In order to see how much the Technion's course web sites, the system features and the local content management systems are being used, four surveys were conducted. In the framework of the first survey all the web sites were reviewed. The reviewers examined the content and the tools being used on each web site. The types of tools were divided into four categories: content tools, communication tools, management tools, and interactive tools. During the second survey a questionnaire was distributed to a sample of about 400 students who had taken the courses for which web sites had been built. The third survey was actually an analysis of the students' responses to the teaching survey that related to the course web site. In the framework of the fourth survey, another questionnaire, which included open and set ques- 


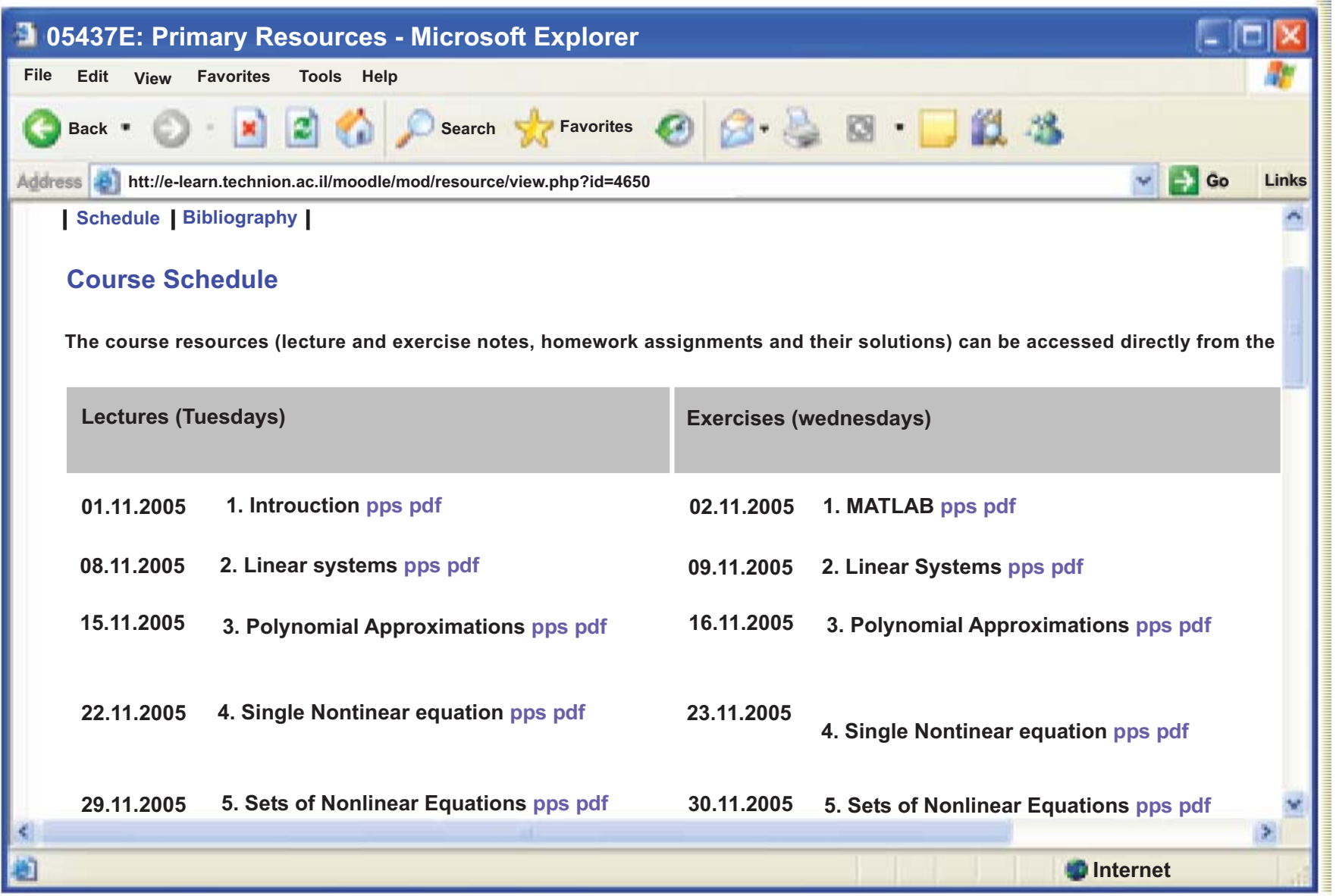

Fig. (1). Course schedule in a chemical engineering course.

tions, was distributed to students who had taken the Technion-wide basic courses in calculus and physics.

The quantitative data collected in the first, second and fourth surveys was analyzed by using the SPSS program and the analysis strategy for the data collected in the third survey involved "content analysis": it defines the analysis units and establishes the categories (outstanding repeated elements) for analyzing the raw data (Denzin \& Lincoln, 1994, p. 358).

The measured variables were: Number of websites based on Moodle, the tools being used on each website, number of active websites, number of lecturers used the interactive features (quizzes, assignments, discussion groups, surveys, glossary and wiki), number of web sites that are not based on Moodle and their content and tools, data collected by the end-of-semester survey, number of students that prefer lecture-based courses over fully on-line courses, and number of lecturers used interactive features.

\section{IMPLEMENTING PRINCIPLES OF THE INSTRUC- TIONAL SYSTEMS DESIGN - MAJOR FINDINGS AND DISCUSSION}

\section{Web Sites Based on Moodle}

Moodle includes the core functionality provided by WebCT, along with some more useful features and pedagogical tools. The design of Moodle had been strongly influenced by an explicit pedagogical theory - social constructionism. The system is technically robust, reliable, and easy to use for both staff and students (McMullin \& Munro, 2004).

Moodle as well as WebCT integrates communication tools, including a bulletin board, chat room/s, private e-mail, and a calendar. In addition, text, graphics, video, and audio files can be incorporated into a course web site. Such features facilitate interaction between faculty and students (Burgess, 2003). Both systems also provide instructional tools to support course content such as a glossary, references, self-tests, and quiz modules. Students, too, can submit assignments and other materials through the system for courses in which they are enrolled. Both systems also give the instructors tools for grading, tracking student interaction, and monitoring class progress.

From an analysis of the findings it was clear that in eight faculties - civil engineering, chemical engineering, biotechnology and food engineering, industrial engineering and management, materials engineering, mechanical engineering, education in technology and science and medicine - the sites are Moodle-based (Table 1). Nonetheless, there are Moodlebased sites in other faculties also. In total, as previously mentioned, approximately 1100 active Moodle-based courses were identified. We consider an active course as a course that has an updated syllabus and lecture presentations, and that $50 \%$, at least, of the registered students enter the web site frequently. In all the Moodle-based sites, administrative data and course content were available. Table 1 pre- 


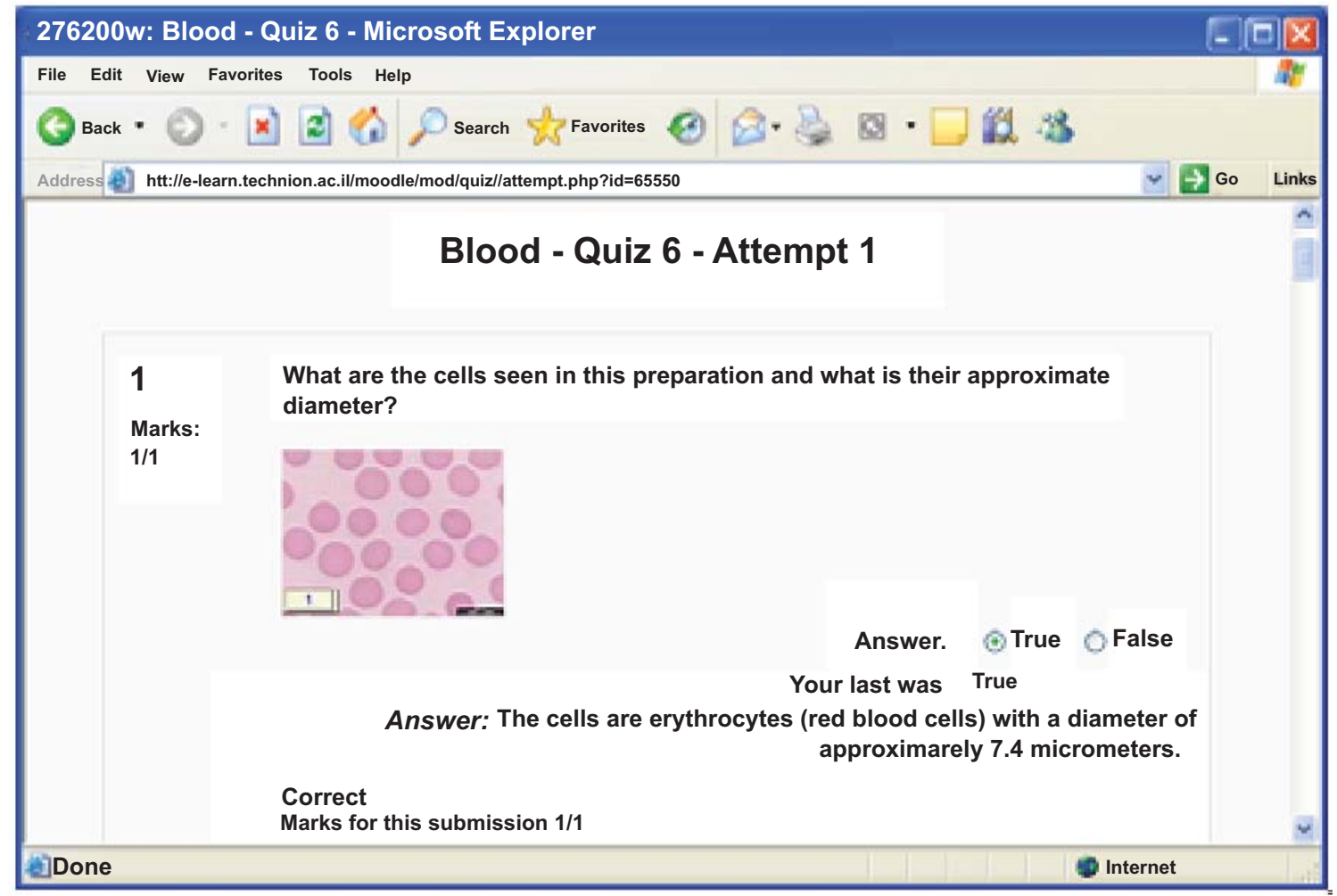

Fig. (2). Interactive quiz in an histology course.

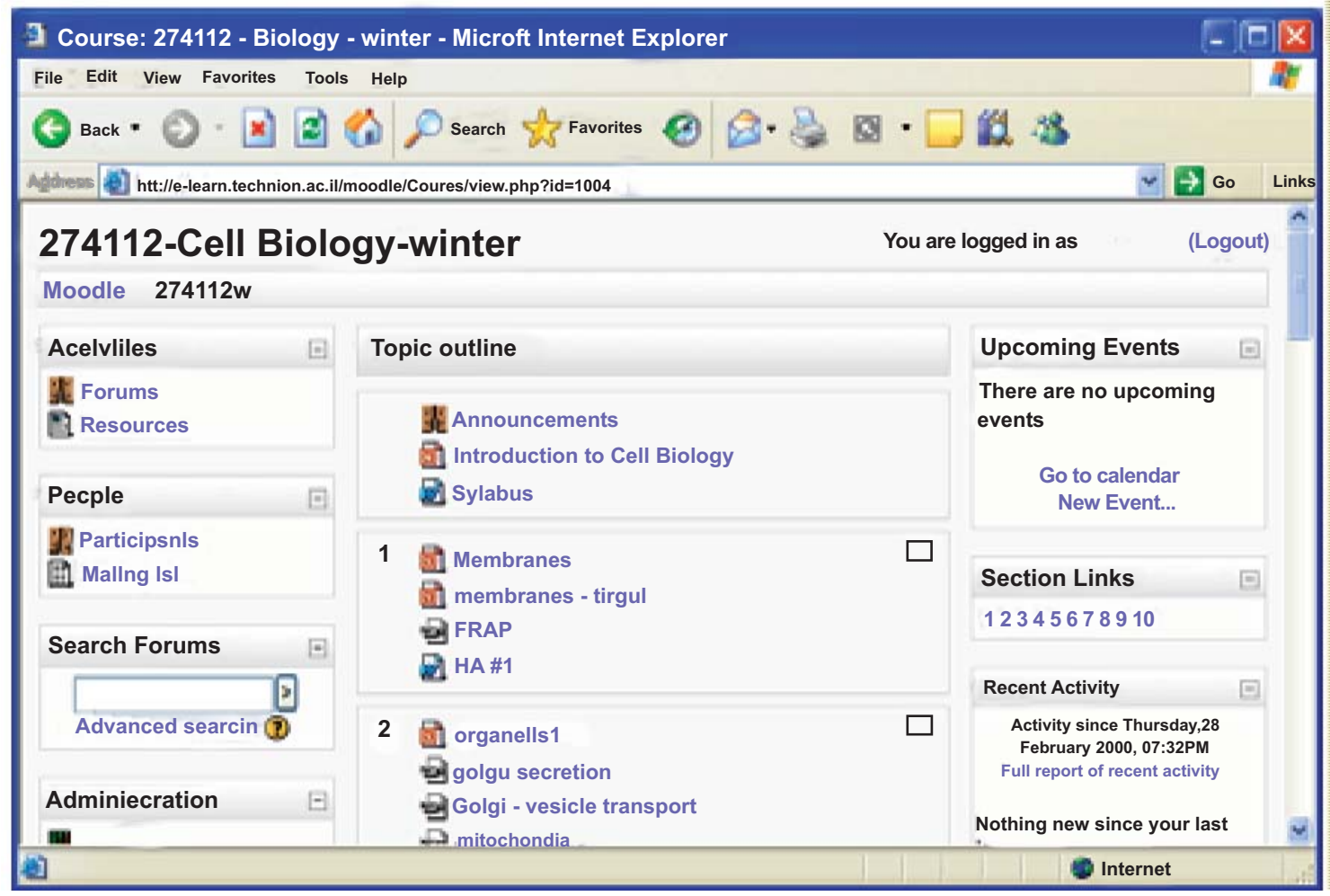

Fig. (3). Outline of a biology course.

sents statistic data demonstrating the numerous usage of Moodle.

In almost all the Moodle-based sites, administrative data and course content were available. However, only about $20 \%$ of the lecturers used the interactive features such as quizzes, assignments, surveys, glossary and wiki (Table 2). Thus, we see that most instructors used their course web sites as a means to enable accessibility to course material and content 
Table 1. Usage of Moodle: Some Statistic Data (Academic Year 2007)

\begin{tabular}{|l|c|}
\hline No. of courses in Moodle & 1102 \\
\hline No. of Logs (Records) per day & $\sim 65,000$ \\
\hline No of undergraduate students per semester & 7811 \\
\hline No of users per semester & $\sim 10,000$ \\
\hline No of resources (content items) & $\sim 36,000$ \\
\hline No. of faculties using faculty CMS & 3 \\
\hline No. of faculties using both Moodle and faculty CMS & 5 \\
\hline No. of faculties using Moodle only. & 8 \\
\hline
\end{tabular}

and to place messages on the bulletin board rather than utilizing the available interactive features. These findings are corroborated in the literature. For example, Burgess (2003, p. 5) found that: "Usage patterns reveal that most WebCT users have not taken full advantage of WebCT capabilities. WebCT as well as other web-based platform were used as a supplement to traditional teaching methods". Dehoney and Reeves (1999) reported on a study that found that the predominant form of web resources among universities were static web pages containing course information and syllabus material. He championed the need for more "pedagogical reengineering" of course materials for web delivery in place of simply enriching conventional courses with web materials.

\section{Teaching Assessment Survey}

As in many other academic institutions, the Technion also carries out end-of-semester surveys among its students in order to measure their degree of satisfaction from the teaching. In the last survey, the pollsters inserted an open question that asked the students to write down their comments about the course web sites (if any). After analysis of their answers, the researchers found that the comments related to six categories - accessibility and availability, integration of multimedia, bulletin boards, group discussions, solutions to home assignments and supplementing lecture material.

Thus, from analyzing the raw data that was collected by the survey, it appears that, in general, the course web sites helped the students' learning. In the courses that had web sites, to a large extent students used them mainly to prepare for lectures, to review lecture material, to deepen their understanding (through the multimedia, for instance), to submit homework assignments, to get feedback and communicate among themselves and with the teaching staff.

The Technion's students are interested in having course web sites that complement the courses in which they are enrolled; still around $85 \%$ of the students stressed the fact that they prefer lecture-based courses over fully on-line courses.

\section{Special Self-Developed Course Web Sites}

Two faculties developed interactive systems dedicated to practice exercises. The mathematics faculty developed Mathnet, a system for doing exercises in subjects such as calculus. The physics faculty developed Physweb for submission of homework assignments in physics. These systems serve thousands of students from different faculties who take Technion-wide core courses. Mathnet has three main modules. The first module allows students to prepare for lectures. Prior to every lecture students are presented with informal background material, followed by several interactive exercises. The second module permits student to receive and submit homework assignments. The third module includes tutorial classes that replace classes given in the past in frontal classroom settings. The system allows students to submit exercises, get grades and receive feedback easily. Students can also address questions to the support staff. Physweb is intended for online submission of homework assignments and receipt of immediate feedback.

Table 2. Moodle's Websites: Usage Type and Percentage of Usage $(\mathrm{N}=1102)$

\begin{tabular}{|l|c|}
\hline \multicolumn{1}{|c|}{ Usage Type } & Percentage of Usage \\
\hline \hline $\begin{array}{l}\text { Content delivery/tools (such as: PPt present- } \\
\text { ations, notes, exercises and solutions, previous } \\
\text { exams and solutions, links, etc. }\end{array}$ & $96 \%$ of the sites. \\
\hline $\begin{array}{l}\text { Management/Communications tools (such } \\
\text { as: Forums, discussion groups, announce- } \\
\text { ments, administrative info, syllabus, grades, } \\
\text { etc. }\end{array}$ & $91 \%$ of the sites. \\
\hline $\begin{array}{l}\text { Interactive tools (such as: Quizes, online tests } \\
\text { with immediate feedback, interactive assign- } \\
\text { ments, peer assessment, simulations, glossary, }\end{array}$ & $20 \%$ of the sites. \\
Wiki, etc.
\end{tabular}

\section{Implications}

Given the essential difference between the two types of systems - LMS and CMS, it is obvious that course web sites built as content sites will not have interactive components. A comparison of Moodle-based web sites and CMS-based web sites shows that the availability of interactive tools occasionally leads, sometimes only, to the use of these tools. Specifically, it seems that the discussion group tool is a less appropriate learning tool in the basic science courses such as mathematics and physics.

Likewise, among lecturers who used the Moodle system, only some added interactive features. Too often the instructional designs that were employed were attempts to apply traditional learning approaches to this new domain. We see, thus, that using features that have pedagogical benefits (such as active learning, immediate feedback, and use of visualization as explained in section 2, above) is still low. The scope of the use of interactive and multimedia applications is still limited. The work program for the Center for e-Learning must stress this area and encourage the addition of interactive features to course web sites. The implementation team should take action and provide additional training to expose the instructors to unused Moodle capabilities.

Taking our findings into consideration and based on the literature review we recommend to consider the following guidelines. The guidelines are classified to four categories according to four dimensions of "good teaching" - organize the course and its content, apply active and interactive learning principles, provide feedback, and use multiple modes of presentation. The first three categories of implications are for 
teachers and the fourth for policy makers. Teachers, policy makers and web site designers should review the list given below, to decide, taking into account the course objectives, what is relevant for their course.

\section{Organize the Course and its Content}

- $\quad$ Provide an overview and an orientation of the entire course web site. Provide information about course objectives, priorities, timelines, and responsibilities. Explain how to use the course web site and how the course content is organized. Specify the instructions regarding exams and quizzes.

- $\quad$ Provide links to relevant programs (such as Autocad or Matlab), including examples and manuals.

- $\quad$ Specify the prior knowledge (prerequisite) that is required for the course. Give short summaries of (or links to) relevant resources.

- Present short summaries of learning material that seems to be hard for students to grasp during the lectures.

- $\quad$ Engage and guide students through the course web site by including elements such as weekly announcement, task-lists, new materials, and forums.

\section{Apply Active and Interactive Learning Principles, Provide Feedback}

- $\quad$ Use discussion groups for peer and/or group assessment and to encourage student expression and reflection.

- Use an FAQ mechanism for handling students' questions. Encourage students to use it.

- Provide self-assessment quizzes to help students monitor their progress. Give the student feedback and guidance.

\section{Use Multiple Modes of Presentation}

- $\quad$ Plan the use of pictures, images, simulations and animations according to the following principles (Kozma, 2003; Lewalter, 2003; Schnotz \& Bannert, 2003; Schnotz \& Lowe, 2003): Students learn more deeply from words and pictures than from words alone; pictures facilitate learning only if the learners have low prior knowledge and if the subject matter is visualized in a task-appropriate way; animations are more effective when the learner can control the pace and the direction.

\section{Establish Support Unit}

- Many faculty members although experts in their professional fields, often lack the proficiency needed to build a website and may need pedagogic guidance in its implementation. Training faculty members and assisting them technically and pedagogically to build their sites is the essence of e-learning project in higher education. Effective use of the technology is a key means of addressing the project challenges. Institutional Support Center must be established to enable faculty members to build and operate their sites and efficiently and effectively implement learning technologies in their courses.
- The support should be provided on two levels:

$\circ \quad$ Pedagogy and technology - creating awareness about using Moodle as a tool for improving teaching; treating pedagogical issues that arise before and during use of Moodle, and providing assistance and support in proper building and management of course web sites.

- Technical support - treating the technical aspects related to shared management of the Moodle system, and solving technical problems that arise.

- The support should be offered in the form of personal guidance and instruction, workshops, and a website providing on-line support. Advanced workshops should also be offered. The workshops should emphasize pedagogical aspects and equip faculty members with an invaluable additional teaching tool, resulting in improved instruction for the students.

\section{CONCLUSIONS}

This paper discusses the issues associated with teaching and learning when developing course web sites based on principles of the instructional systems design (ISD) approach. The paper reviews the benefits and challenges of using course web sites in lecture-based teaching. The advanced technology exists but using technology simply because it is there does not assure effective learning. More important are the pedagogical considerations and the ways of using the technology to extract more of the pedagogical benefits.

The technology should be used to drive active learning, give immediate feedback, and present external and internal multiple representations in multimedia learning. In using discussion groups, other interactive features, and inquirybased approaches, teachers can nurture a learning environment that enables students to create their own meaning, and organize and rationalize their personal experiences. Examining experience fosters learning (Fosnot, 1996). Technology should be used to serve pedagogical needs and to enable meaningful learning.

Many examples exist to guide instructors in the design of more innovative and dynamic course web sites. Yet, there is still a tendency for instructors in engineering education to build course web sites that underutilize the technology's potential. This tendency can be seen to stem from difficulties that teachers face in moving from teacher-centered to resource-based learning (Oliver \& McLoughlin, 1999). While motivational issues should be taken into consideration, teacher should use technology for creating a learning environment that assures: "Overall, students find electronic interaction a meaningful, enjoyable experience" (LaMaster \& Morley, 1999).

\section{REFERENCES}

Ash, C. (2000). Towards a New Cost-Aware Evaluation Framework. Educational Technology \& Society 3(4),

Banathy, B.H. (1987). Instructional Systems Design. In R.M. Gagne (Ed.), Instructional Technology: Foundations. Hillsdale, NJ: Lawrence Erlbaum Associates. 
Bhattacharya, M. (1999). A study of asynchronous and synchronous discussion on cognitive maps in a distributed learning environment. Proceedings of the WEBNET 99 World Conference on the WWW and Internet. Honolulu, Hawaii, October 24-30.

Black, P., \& Wiliam, D. (1998). Inside the black box: Raising standards through classroom assessment. Phi Delta Kappan, 80 (2), 139-144.

Branon, R. F., \& Essex, C. (2001). Synchronous and asynchronous communication tools in distance education. TechTrends. 45 (1), 36-42.

Brinkerhof, J., \& Koroghlanian, C. M. (2005). Student computer skills and attitudes toward internet-delivered instruction: An assessment of stability over time and place. Journal of Educational Computing Research, 32 (1), 27-56.

Brown, B.L. (2000). Web-Based-Training. Washington, DC: Office of Educational Research and Improvements. (ERIC Document Reproduction Service No. EDO-CE-00-218).

Burgess, L. A. (2003). WebCT as an e-learning tool: A study of technology students' perceptions. Journal of Technology Education, 15 (1), 615.

Cobern, W. (1993). Contextual constructivism: The impact of culture on the learning and teaching of science. In K. G. Tobin (Ed.), The practice of constructivism in science education. Hillsdale, NJ: Lawrence Erlbaum Associates.

Commonwealth of Learning (2003). COL LMS Open Source. Available at:

http://www.col.org/colweb/webdav/site/myjahiasite/shared/docs/03 LMSOpenSource.pdf

Cronbach, L. J. (1977). Educational psychology. New York: Harcourt Brace Jovanovich.

Crooks, T. J. (1988). The impact of classroom evaluation practices on students. Review of Educational Research, 58 (4), 438-481.

Dehoney, J., \& Reeves, T. (1999). Instructional and social dimensions of class web pages. Journal of Computing in Higher Education, 10 (2), 19-41.

Denzin, N. K. \& Lincoln, Y. S. (1994). Handbook of Qualitative Research. Thousand Oaks: Sage.

Early, P. C. (1988). Computer-generated performance feedback in the magazine-subscription industry, Organizational Behavior and $\mathrm{Hu}$ man Decision Processes, 41, 50-64.

Frank, M., Reich, N., \& Humphreys, K. (2002). Respecting the human needs of students in the development of e-learning. Computers \& Education, 40 (1), 57-70.

Freedman, Y. (1998). Teachers and Students - Mutual Respect Relationships. Jerusalem: Henrietta Szold Institute for Social Sciences Research (in Hebrew, abstract in English).

Garrison, D.R., Anderson, T., \& Archer, W. (2000). Critical thinking in a text-based environment. Computer Conferencing in higher education. Internet in Higher Education, 2(2), 87-105.

Glasersfeld, E.V. (1995). A constructivist approach to teaching. In P. Leslie, \& J. Gale (Eds.), Constructivism in education. Hillsdale, New Jersey: Lawrence Erlbaum Associates.

Hake, R. R. (1998). Interactive-engagement versus traditional methods: A six-thousand-student survey of mechanics test data for introductory physics courses. American Journal of Physics, 66 (1), 64-74.

Hativa, N. (2000). Teaching for effective learning in higher education. Dordrecht, The Netherlands: Kluwer Academic Publishers.

Hill, A. M. (1997). Reconstructionism in technology education. International Journal of Technology and Design Education, 7 (1-2), 121139.

Hill, J. R. (1997). Distance learning environments via the world wide web. In H. K. Badrul (Ed.), Web-based instruction. Englewood Cliffs NJ: Educational Technology Publications.

Jackson, B. (1988). A comparison between computer-based and traditional assessment tests, and their effects on pupil learning and scoring. School Science Review, 69, 809-815.

Kluger, A.N., \& DeNisi, A. (1996). The effects of feedback interventions on performance: A historical review, a meta-analysis and preliminary feedback theory. Psychological Bulletin, 119, 254-284.
Kozma, R. (2003). The material features of multiple representations and their cognitive and social affordances for science understanding. Learning and Instruction: The Journal of the European Association for Research on Learning and Instruction, 13 (2), 205-226.

Krajcik, J., Czerniak, C., \& Berger, C. (1999). Teaching children Science: A project-based approach. New York: McGraw-Hill College.

Kumar, D. D., \& Helgeson, S. L. (2000). Effect of gender on computerbased chemistry problem solving. Electronic Journal of Science Education. 4 (4), Retrieved May 12, 2007, from http://unr.edu/homepage/crowther/ejse/kumaretal.html

LaMaster, K. J., \& Morley, L. (1999). Using WebCT bulletin board option to extend transitional classroom walls. (ERIC Reproduction Service No ED 440 922).

Lewalter, D. (2003). Cognitive strategies for learning from static and dynamic visuals. Learning and Instruction: The Journal of the European Association for Research on Learning and Instruction, 13 (2), 177-190.

Lister, B. C. et al. (1999). The Rensselaer 80/20 model for interactive distance learning. Proceedings of Educause 99. Long Beach, CA, October 26-29. Retrieved May 7, 2007, from http://www.educause.edu/ir/library/html/edu9907/edu9907. html

Locke, E. A., \& Latham, P.L. (1990). A theory of goal setting and task performance. Englewood Cliffs, NJ: Prentice-Hall.

Lowe, R. K. (2003). Animation and learning: selective processing of information in dynamic graphics. Learning and Instruction: The Journal of the European Association for Research on Learning and Instruction, 13 (2), 157-176.

Mayer, R. E. (2003). The promise of multimedia learning: using the same instructional design methods across different media. Learning and Instruction: The Journal of the European Association for Research on Learning and Instruction, 13 (2), 125-140.

McMullin B. \& Munro M. (2004). Moodle at DCU. Retrieved May 7, 2007, from http://odtl.dcu.ie/wp/2004/odtl-2004-01.html

Montgomerie, T.C. \& Harapnuik, D (1997). Observations on web-based course development \& delivery. International Journal of Educational Telecommunications, 3 (2-3), 181-203.

Natriello, G. (1987). Evaluation processes in schools and classrooms. Baltimore, MD: Johns Hopkins University, Center for Social Organization of Schools.

Oliver, R., \& McLoughlin, C. (1999). Curriculum and learning-resources issues arising from the use of web-based course support systems. International Journal of Educational Telecommunications, 5(4), 419-435.

Schnotz, W., \& Bannert, M. (2003). Construction and interference in learning from multiple representations. Learning and Instruction: The Journal of the European Association for Research on Learning and Instruction, 13 (2), 141-156.

Schnotz, W., \& Lowe, R. (2003) Introduction. Learning and Instruction: The Journal of the European Association for Research on Learning and Instruction, 13 (2), 117-124.

Strijbos, J.W., Martens, R., Jochems, W. \& Broers, N. (2007). The effect of functional roles on perceived group effiancy during computersupported collaborative learning: A matter of triangulation. Computers in Human Behavior, 23, 353-380

Tu, C-H., \& McIsaac. M. (2002). The relationship of social presence and interaction in online classes. American Journal of Distance Education, 16(3), 131-150.

Willis, B., \& Dickinson J. (1997). Distance education and the world wide web. In H. H. Badrul (Ed.), Web based instruction. Englewood Cliffs. NJ: Educational Technology Publication.

Wiliam, D. (2002). Notes towards a theory of formative assessment. Paper presented at the joint Northumbria/EARLI assessment conference: Learning communities and assessment cultures, connecting research with practice. Newcastle, UK, 28-30 August.

Wolcott, L. (1995). The distance teacher as reflective practitioner. Education in Technology, 34 (3), 49-55. 